\title{
FRESH WATER RESOURCES IN THE NATURA 2000 PRICOP- HUTA CERTEZE AND TISA SUPERIOARĂ PROTECTED AREAS
}

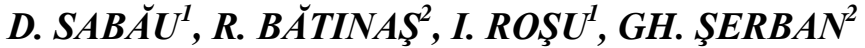

\begin{abstract}
Fresh Water Resources in the Natura 2000 Pricop-Huta Certeze and Tisa Superioară Protected Areas. The Transcarpatic Basin which includes the Maramureş Basin (and within it the PHCTS area) is the largest intra-Carpathian lowland area, structured on a substrate with different geology, consisting in igneous rocks and crystalline schists, in the high areas and sandstones, conglomerates, marl, clay and sands in the central lower part. These features along with important rainfall amounts (up to 1800 $\mathrm{mm}$ in Ukrainian side) create conditions for a surplus in water resources budget, along with extreme hydrological events which are becoming very common. The average discharge values in PCHTS area go up to $40 \mathrm{l} / \mathrm{s} . \mathrm{km}^{2}$ in high mountain area, while in the lowland space the values are around to $5 \mathrm{l} / \mathrm{s} . \mathrm{km}^{2}$. Although, the surface water resource is plentiful its capitalization is facing serious problems due to pollution of various origins, from the one related to former mining activities, to those linked to the existence of human habitats which provides different residues. As for the underground water resource, the relatively impermeable substrate creates poor conditions for reserves accumulation and gives unfavorable chemical properties for accumulated water. Overall, water balance is in surplus with rainfall values nearly double compared to the drainage ones and aridity index values which barely exceed 0.5 .
\end{abstract}

Keywords: petrographic mosaic, important rainfall amounts, rich discharge flow, positive water balance, low aridity index, limited usable resources.

\section{INTRODUCTION}

The existence of magmatic and crystalline schists in Basin of Maramureş is expressed into a massive relief and a peripheral amplitude of the basin, but also on the presence of high morphological structures with altitudes exceeding 2,000 meters in the south-eastern part of the region. The relief landscape is diverse, ranging from meadows and valley corridors to mountain ranges (Posea et al., 1980; Ardelean et al., 2000; Boar, 2005; Chiş \& Kosinszki, 2011) (Fig. 1).

The sedimentary component characterizes the lower areas inside the area, and together with other petrographic formations, imprint quantitative and qualitative features to water bodies in the studied region (Romania Geological Map 1: 200,000 Baia Mare and Vişeu sheets).

The average multiannual values of rainfall are high and are increasing with altitude: in lower Basin of Maramureş multiannual values ranges around $700 \mathrm{~mm}$, significantly increasing over $1200 \mathrm{~mm}$ in Rodna, Ţibleş, Igniş, Gutâi and Oaş

1 “Romanian Waters” National Administration - „Someş-Tisa” Water Branch, 17 Vânătorului, 400213, Cluj-Napoca, Romania, e-mail: andrei.sabau@dast.rowater.ro, ioan.rosu@dast.rowater.ro

2 "Babeş-Bolyai" University, Faculty of Geography, 5-7 Clinicilor, 400006, Cluj-Napoca, Romania, e-mail: razvan.batinas@ubbcluj.ro,gheorghe.serban@ubbcluj.ro 
Mountains and exceeding $1400 \mathrm{~mm}$ in Mountains of Maramureş. On the Ukrainian side they grow, up to $1800 \mathrm{~mm}$ (Ujvari, 1972; Cocuţ, 2008; Chiş \& Kosinszki, 2011).

In the Pricop-Huta Certeze and Tisa Superioară (PHCTS) protected areas there is almost similar a situation, because the maximum multiannual values of average rainfall are very close to $1400 \mathrm{~mm}$ in the two peripheral areas situated on the west part (Oaş Mountains) and eastern part (Mountains of Maramureş), while in the centre of the area they are not exceeding $1300 \mathrm{~mm}$ in Igniş Massif (Ujvari, 1972; Cocuţ, 2008).

The multiannual minimum average rainfall values are close to $700 \mathrm{~mm}$, and are found on major valley corridors, like: Tisa, Iza and Vişeu, except the western periphery of PHCTS areas, where the values are close to $600 \mathrm{~mm}$.

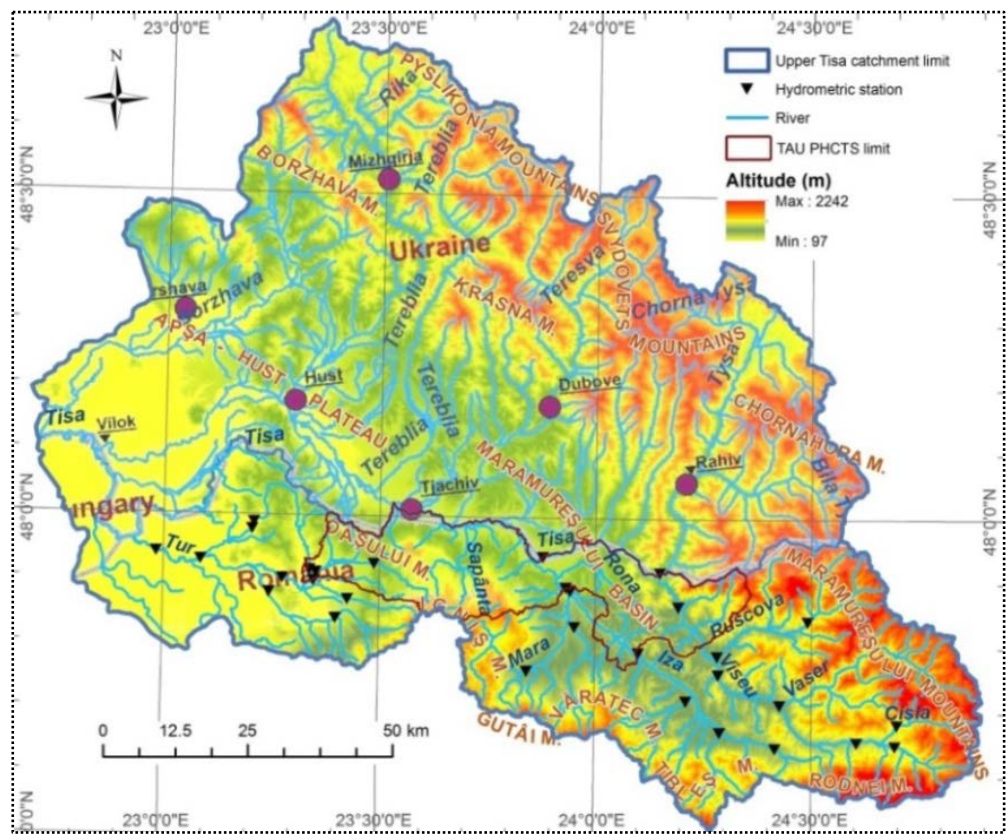

Fig. 1. Upper catchment of Tisa River (adapted and supplemented, including spatially, after Lukianets and Obodovskyi, 2015)

Evapotranspiration multiannual average values in the PHCTS areas are low (295 $\mathrm{mm}$ in the mountainous eastern area) and do not exceed $668 \mathrm{~mm}$ in the western lowlands (Ujvari, 1972; Cocuţ, 2008; Clima României, 2008).

Upper Tisa, is forming for a distance of $62 \mathrm{~km}$ the natural border between Romania and Ukraine, between Valea Vişeului and Piatra localities. It is composed by the confluence of two rivers: Black Tisa and White Tisa which are springing from Carpaţii Păduroşi Mountain Range, respectively from Svidoveţ Mountain $(1183 \mathrm{~m})$ and Cernagora Mountain $(2058 \mathrm{~m})$. The Upper Tisa basin in Romania covers an area of $4540 \mathrm{~km}^{2}$, with an average slope of $2 \%$ and gathers 115 rivers with catchments areas greater than $10 \mathrm{~km}^{2}$, with a total length of $1557 \mathrm{~km}$.

The main autochthonous watercourses collected by Tisa are Vişeu River with an area of $1581 \mathrm{~km}^{2}$ and a total length of $82 \mathrm{~km}$, Iza River with an area of $1293 \mathrm{~km}^{2}$ and a 
total length of $80 \mathrm{~km}$, Săpânţa and Şugătagul Mare - the latter less important, all left tributaries flowing on a SE-NW direction. The density of river network in the study area is between $0.5 \mathrm{~km} / \mathrm{km}^{2}$ in the lower part of the basin and $0.8 \mathrm{~km} / \mathrm{km}^{2}$ in the mountains.

\section{SURFACE WATER RESOURCES IN PHCTS AREA}

The technically usable water resources in the upper Tisa Basin are important quantitatively, but they could change in time, and can, thus, be unavailable for the water management company ("Romanian Waters" National Administration-,,Someş-Tisa” Water Branch Administration - S.T.W.B.A., 2010):

- Surface water - 250 mil. $\mathrm{m}^{3}$

- Groundwater 50-106 million. $\mathrm{m}^{3}$

The most important parameter that characterizes water resources in rivers is the average annual discharge, expressed either as volume spilled, either as discharge flow (Table 1).

Table 1. The distribution of water resources in the basin of Romanian Upper Tisa (average annual values and related to a dry year 1990) ("Romanian Waters" National Administration - R.W.N.A., 2013)

\begin{tabular}{|c|c|c|c|c|c|c|}
\hline \multirow{2}{*}{$\begin{array}{c}\text { River basin } \\
\text { district }\end{array}$} & \multirow{2}{*}{$\begin{array}{l}\text { Area } \\
\left(\mathbf{k m}^{2}\right)\end{array}$} & \multicolumn{2}{|c|}{ Average conditions } & \multicolumn{3}{|c|}{ Dry year 1990} \\
\hline & & $\begin{array}{c}\text { Annual average } \\
\text { flow }\left(\mathrm{m}^{3} / \mathrm{s}\right)\end{array}$ & $\begin{array}{l}\text { Volume } \\
\left(\text { mil. } \mathbf{m}^{3}\right)\end{array}$ & $\begin{array}{c}\text { Average flow } \\
\left(\mathrm{m}^{3} / \mathrm{s}\right)\end{array}$ & $\begin{array}{l}\text { Volume } \\
\left(\text { mil. } \mathbf{m}^{3}\right)\end{array}$ & $\frac{\mathrm{Q} 1990}{\left(\mathrm{~m}^{3} / \mathrm{s}\right)}$ \\
\hline Upper Tisa & 4540 & 66 & 2082 & 50 & 1578 & 76 \\
\hline
\end{tabular}

\subsection{Average liquid flow}

For Tisa River, on the exiting point out of Romania, we calculated an annual average flow of $130 \mathrm{~m}^{3} / \mathrm{s}$ - with all Ukrainian Basin (specific flow of 20.2 $\mathrm{l} / \mathrm{s} . \mathrm{km}^{2}$ ), with important hydrological contribution from the Romanian territory rivers like Vişeu $\left(33.9 \mathrm{~m}^{3} / \mathrm{s}\right)$ and Iza $\left(16.6 \mathrm{~m}^{3} / \mathrm{s}\right)$. Tisa River has a specific discharge rate three times higher than Someş, while the Tisa basin area although it is half, due to heavy rainfall recorded into the catchment area (S.T.W.B.A., 2015).

Specific average flow is the amount of water that flows per unit time per unit area. This parameter can be calculate with the following relationship:

$$
q=Q \cdot 10^{3} / F\left(1 / \mathrm{s} . \mathrm{km}^{2}\right)
$$

where: $\mathrm{q}$ - specific average flow, in $\mathrm{l} / \mathrm{s} . \mathrm{km}^{2}$;

$\mathrm{Q}$ - discharge value, in $\mathrm{m}^{3} / \mathrm{s}$;

$\mathrm{F}$ - catchment area, in $\mathrm{km}^{2}$.

Elevated values of specific average flow derives from a rich feeding developed in the mountains, confirmed by high levels of precipitation, analyzed above. The catchment areas situated at high altitudes are approaching values of $40 \mathrm{l} / \mathrm{s} . \mathrm{km}^{2}$, while on

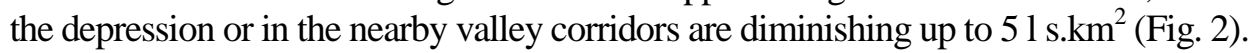

\subsection{Types of rivers regimes in the PHCTS areas}

The study of hydrological regime aims to emphasize the governing laws of time and space variation of water resources from a certain area. 


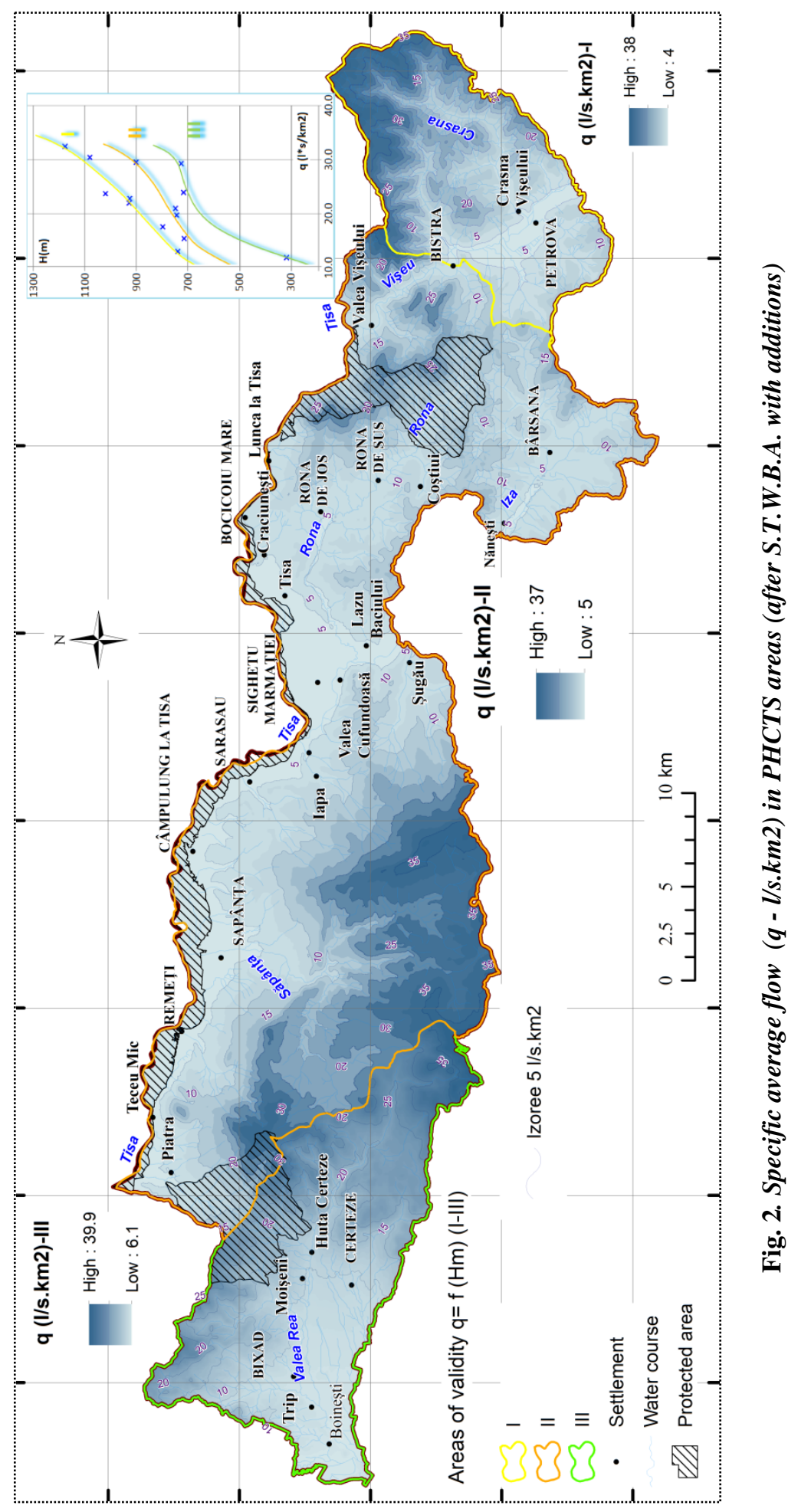


In this sense, the knowledge of drainage regime has great practical significance because the local and regional socio-economic development, depends on the quantity and variation in time and space of water resources.

By studying the characteristics of the water flow regime within the PHCTS area - related spatial component of River Tur basin, it can be confirmed, that is belonging to the Carpathian (C) type of regime in lowland and mountainous area and to the Pericarpathian (Pc) type in the lowlands.

Tisa River and its tributaries, in the area of interest, has a hydrological regime of the Western Carpathian type, with the maximum volume of the flow in April and the lowest volume in winter (Ujvari 1972 and 1980).

Although, the quantities of water from rivers, available to the local population is more than enough, their quality is problematic in use, due to several reasons: pollution with hazardous substances from the former mining areas (Vişeu River and its collector Tisa - Smical et al., 2015), pollution with waste from localities networks with a high density on the lower relief areas, high levels of turbidity produced due to frequent and important quantitative rainfall, high discharge flow derivation towards other catchment areas - Mara Basin case etc.

\section{GROUNDWATER RESOURCES IN PHCTS AREAS}

Groundwater is an important resource in particular because of their physico-chemical and biological quality. The possibility of storage and movement of groundwater is closely related to lithological composition, spatial arrangement and feeding conditions, factors that determine, in fact, hydraulic conditions of the aquifers. Thus, we can found phreatic and deep groundwater.

Phreatic groundwater are distributed in Romania in three macro-regions, Carpathian Orogen, depressions and intracarpathian basins, depressions and extracarpathian basins. Mountains region of the Carpathian Orogen shows little interest in terms of water supply by drilling and therefore are not included in the estimates of groundwater resources (R.W.N.A., 2013).

The hydrogeological macro-region forming the greath basins and intercarpathian basins include Western Plain, Transylvanian Basin and Basin of Maramureş, extensive sedimentary units, clearly defined tectonic, genetically and morphologically. In these regions the average groundwater flows have values between 0.1 and $1.5 \mathrm{l} / \mathrm{s} . \mathrm{km}^{2}$ for Western Plain and between 0.1 and $1.0 \mathrm{l} / \mathrm{s} . \mathrm{km}^{2}$ in the Transylvanian Basin and lower Basin of Maramureș (R.W.N.A., 2013).

The deep waters with ascending or artesian nature are widely distributed in sedimentary Carpathian regions, ranging up to depths of several thousand meters, but almost completely absent in areas with compact rocks. Carpathian ridge have a watershed role against the surrounding depression regions. But within them there are tectonic depressions or structures that are favouring deep water accumulation with ascending nature.

Identification and delineation of groundwater bodies was made only for areas where have been found significant aquifers with importance for water supply systems, with exploitable flow rates greater than $10 \mathrm{~m}^{3} /$ day. The rest of the area, even if there are local water accumulation conditions underground, they do not 
constitute bodies of water, according to the Water Framework Directive 60/2000 / EC (S.T.W.B.A., 2010).

The geological criterion is defined not only by evaluating the age of underground water deposits, but also by the petrographic and structural features, and their properties or ability to store water. Thus have been demarcated and characterized by three types of groundwater bodies: porous, fissure and karst type.

The hydrodynamic criterion is acting especially in connection with the expansion of water bodies. Thus, phreatic water bodies have extension only up to the basin watershed line that corresponds to their bodies, while depth water bodies may extend outside the basin.

The groundwater bodies code (e.g. ROSO02) has the following structure: $\mathrm{RO}=$ country code, $\mathrm{SO}=$ "Someş-Tisa" Water Basin Administration 02 = number of water body in the "Someş-Tisa" Water Basin Administration (S.T.W.B.A., 2010) (Fig. 3).

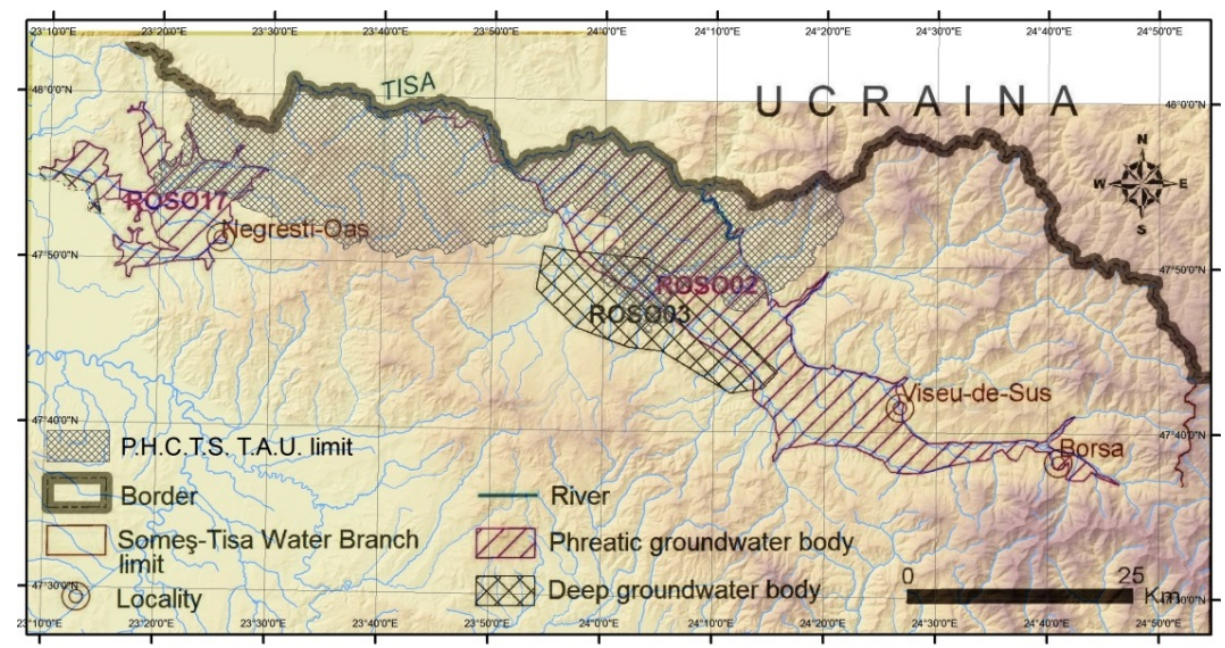

Fig. 3. Delineation of underground water bodies in „Someş-Tisa” Water Basin Administration (after S.T.W.B.A., 2010, with additions)

The identified groundwater bodies are associated with the porous type, being accumulated into deposits of Quaternary and Pannonian age and fissure type or mixed karst-fissure or fissure-porous developed into deposits of flowing ages: Triassic-Cretaceous, Palaeocene-Miocene and the Palaeogene-Quaternary (Fig. 4).

Two groundwater bodies (ROSO02 and ROSO17) have been identified in areas of floodplains and terraces of different tributaries of Tisa and Tur River. They are developed into porous permeable alluvial-proluvial deposits, of recent age, particularly Quaternary.

Being located close to the surface, they have a free level. The ROSO03 water body (lower Basin of Maramureş), although it is under pressure, is situated in Pannonian age deposits and has a low economic importance (S.T.W.B.A., 2010).

\subsection{The ground water body ROSO02 - Iza and Vişeu Rivers}

This phreatic water body develops in lower Basin of Maramureş, largely overlapping the Vişeu catchment and partly over the upper basin of Iza River (Fig. 3). 


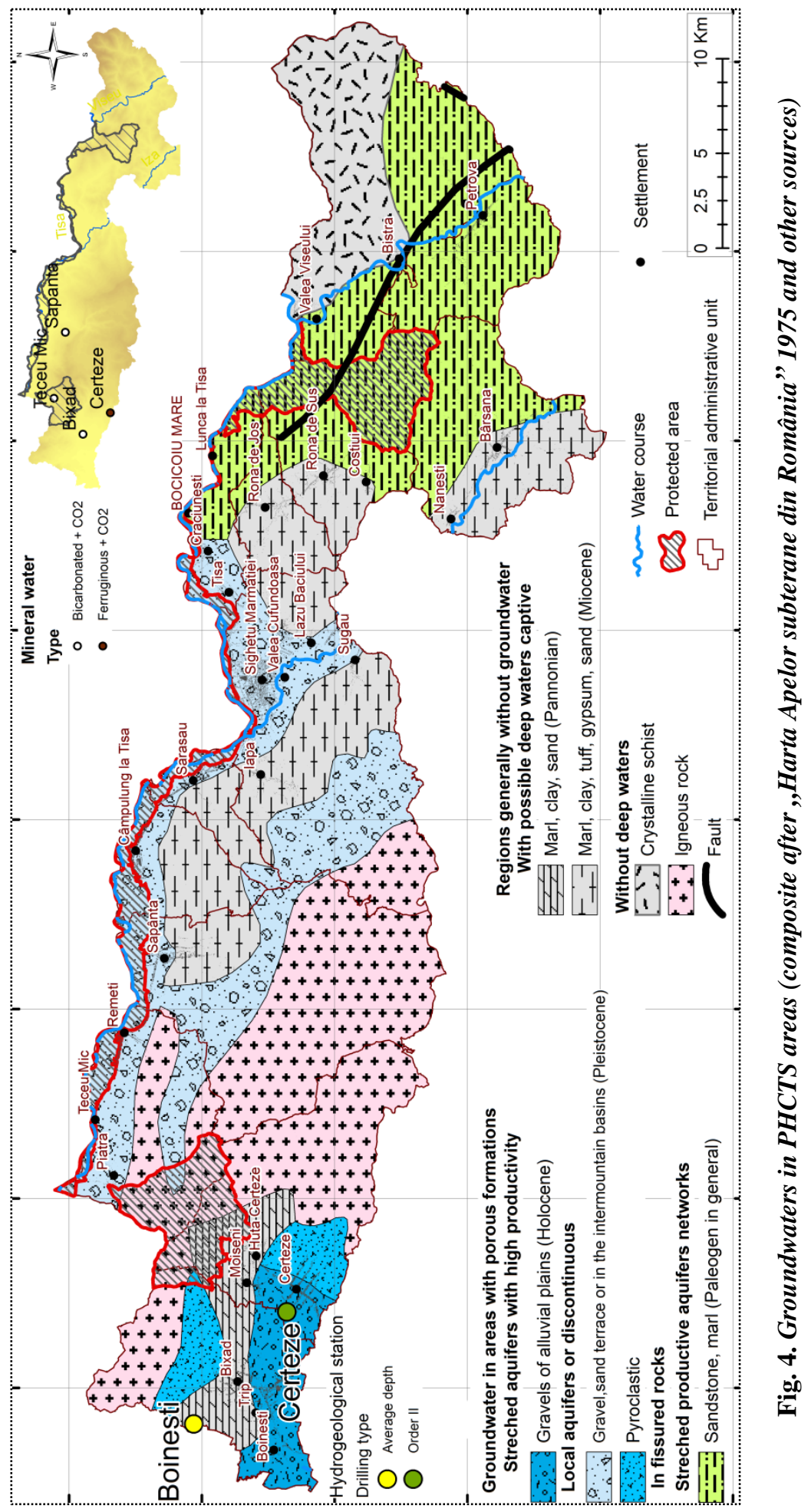


Petrographic constitution of this area, is marked by the dominant presence of sandstones, conglomerates and Palaeocene sands, with relatively high permeability, which became the support of a fissured stretched network (Fig. 4).

The average modulus of flow from the fissured groundwater aquifer system is 7-10 l/s.km², which means a feed rate of $250 \mathrm{~mm} /$ year (S.T.W.B.A., 2010).

It was highlighted also the existence of springs, whose flow varies between 0.2 and $1 \mathrm{l} / \mathrm{s}$, with a permanent regime. The phreatic aquifer from floodplains and river terraces of Iza and Vişeu, consists of gravel and boulders 4-6 m thick, with levels standpipes located at $0.1-3.0 \mathrm{~m}$ and very low pumping flow rates (less than $0.1 \mathrm{l} / \mathrm{s} / \mathrm{drilling}$ ). The only sub-areas in which there were significant flow rates ranging between 0.7 and $7 \mathrm{l} / \mathrm{s} /$ drilling for unevenness of $0.3-1.3 \mathrm{~m}$ are located at Borşa and Vişeu de Sus (S.T.W.B.A., 2010).

\subsection{The ground water body ROSO03 - lower Basin of Maramureş}

The deep ground water body is a fissured type and is hosted in MiocenePalaeogene age deposits. In order to determine the possible supply of drinking water to communities throughout this water body, have been carried out some investigation boreholes which have led to the following conclusions (S.T.W.B.A., 2010):

- The drilling executed at Călineşti, at a depth of $250 \mathrm{~m}$, has captured on 135-160 m and 191-216 m intervals a sandstone complex, with a maximum flow value of $0.3 \mathrm{l} / \mathrm{s}$, for a bump of $34 \mathrm{~m}$ (piezometric level is artesian to $+0.23 \mathrm{~m}$ ). The water is potable, being framed into the calcium bicarbonated, magnesian, sodic type with a small concentration of nitrates of less than $2 \mathrm{mg} / \mathrm{l}$;

- The drillings at Sighetu Marmaţiei, Deseşti and Bogdan Vodă, at depths between 250-300 m, have been unsuccessful in hydrogeological terms.

\subsection{The ground water body ROSO17 - Upper Tur Plain}

The phreatic groundwater aquifer, of porous and permeable type, is located in the alluvial deposits, from meadow and terrace, of Quaternary age, on the Upper Tur River and its tributaries (Negreşti Oaş Basin). Downstream of Călineşti village, this ground water body comes into direct contact with the body ROSO01 - Someş cone (S.T.W.B.A., 2010) (Fig. 3 and 4).

In terms of lithology, deposits are made, in the floodplains and terraces areas, of sand, silty sands, gravel sands, gravels and sands with boulders, with clay floors looking lentiliform. Local can be found also clayey sands with gravel and boulders. In marginal areas of depression developing dejection nested cones can appear (Fig. 4).

In areas of floodplains and terraces the thickness of alluvium deposits is generally between 3-10 m, but can reach up to $28 \mathrm{~m}$ in the Coca village area. The aquifer bed is formed in the Pannonian marl and clay, while its upper side developed under the soil strata is defined without a continuous surface, by clay, sandy clay and silty clay. The thickness of these deposits vary between 0.5 and $4 \mathrm{~m}$ (S.T.W.B.A., 2010).

The hydrostatic level is generally free, or can be slightly upwardly when the roof aquifer develops clay formations. The depth at which the hydrostatic level vary widely, between 0.07 and $2.15 \mathrm{~m}$, but the average value is 0.2 to $1.25 \mathrm{~m}$. The specific flow is very small values of 0.025 to $0.135 \mathrm{l} / \mathrm{s} / \mathrm{m}$ (S.T.W.B.A., 2010). 
The aquifer is feeding mainly from precipitation; the effective infiltration has values from 31.5 to $63 \mathrm{~mm} /$ year. The direction of groundwater flow is generally from aquifer to the river, but during high waters phenomena, the flow direction can be reversed.

The possibilities for water supply for settlements in Maramureşului Depression from the geological formations that are developing up to a depth of 300 $\mathrm{m}$, are extremely low. This fact, reconfirm the conclusion that this morphohydrographic unit is poor in groundwater.

\section{WATER BALANCE IN PHCTS AREAS}

The concept of water balance means the quantitative relationship between incoming and outgoing quantities of water from an area within a specified time period. The difference between the volumes of water in and out of the area analyzed is the water reserve. In determining the water balance of the studied area were used average values of the equation for the period 1954-2005, expressed in mm.

The first map of our country aridity index was drawn up by Ioan C. (1929). Later Ujvari and Gâştescu (1958) have drawn map isolines aridity index, on which are three humidity areas: rich $(\mathrm{Ka}<0.8)$, variable $(\mathrm{K}=0.8-1.2)$ and poor $(\mathrm{Ka}>1.2)$.

In order to assess the water balance elements in PHCTS areas has been used the water balance simplified equation set by A. Penck: $X=Y+Z$, where $X$ represents precipitation, $\mathrm{Y}$ represents the drainage and $\mathrm{Z}$ is global evaporation. Besides these values, were also calculated aridity index values $(\mathrm{Ka})$, to reflect better the surplus flow derived from surplus moisture in the area. The index is the ratio between the annual amount of evaporated water (Z) and average annual rainfall (X): K = Z / X (Table 2).

Table 2. The structure of water balance in PHCTS areas (informations provided by S.T.W.B.A. and other sources)

\begin{tabular}{|c|c|c|c|c|c|c|c|c|c|c|c|}
\hline \multirow{2}{*}{$\begin{array}{l}\text { Element/Are } \\
\text { a of validity }\end{array}$} & \multirow{2}{*}{$\begin{array}{c}F \\
\left(\mathbf{k m}^{2}\right)\end{array}$} & \multicolumn{3}{|c|}{ Precipitation (X) } & \multicolumn{3}{|c|}{ Global leak (Y) } & \multicolumn{3}{|c|}{$\begin{array}{c}\text { Evapotranspiration } \\
\text { (Z) }\end{array}$} & \multirow{2}{*}{$\begin{array}{c}\text { Aridity } \\
\text { index }\end{array}$} \\
\hline & & mm & $\underset{\mathrm{m}^{3}}{\mathrm{mil} .}$ & $\%$ & $\mathbf{m m}$ & $\underset{\mathbf{m}^{3}}{\mathrm{mil} .}$ & $\%$ & $\mathbf{m m}$ & $\begin{array}{c}\text { mil. } \\
\mathbf{m}^{3}\end{array}$ & $\%$ & \\
\hline $\mathrm{I}$ & 127.91 & 940 & 120.24 & 14.06 & 482 & 61.65 & 14.57 & 379 & 48.48 & 9.67 & 0.40 \\
\hline II & 621.41 & 898 & 558.03 & 65.26 & 412 & 256.02 & 60.49 & 577 & 358.55 & 71.53 & 0.64 \\
\hline III & 183.29 & 965 & 176.87 & 20.68 & 576 & 105.58 & 24.94 & 514 & 94.21 & 18.80 & 0.53 \\
\hline $\begin{array}{c}\text { Total } \\
\text { PHCTS }\end{array}$ & 932.61 & 934.3 & 855.14 & 100 & 490.0 & 423.25 & 100 & 490.0 & 501.24 & 100 & 0.52 \\
\hline
\end{tabular}

Significant amounts of precipitation and water flow, combined with low evapotranspiration, places the study area into the excessive and moisture rich zone (Ujvari, 1972; Cocuţ, 2008).

\section{CONCLUSION}

The studied area is deficient in free level (phreatic) and deep groundwater deposits. Thus, in order to ensure the drinking water supply needs, there should be used surface resources which can be stored in reservoirs or the capitalization of the most important existing sources. Surface water quality also imposes some 
restrictions on water use due to pollution from former mining activities, the human habitats and the chemical composition of water resource determined by sedimentary substrate.

Acknowledgments. This paper was made possible by the financial support obtained in the project RO02 - 0013 - Integrated study concerning the contribution of ecosystems from the Pricop-Huta-Certeze and Tisa Superioară Natura 2000 protected areas, to the sustainable development of local communities (SIENPHCTS), funded through a grant awarded by Iceland, Liechtenstein and Norway, on the RO02 - Biodiversity and ecosystem services program, the call for projects proposals No. 1, whose Programme Operator is the Ministry of Environment.

\section{REFERENCES}

1. Ardelean G., Béreş I. (2000) Fauna de vertebrate a Maramureşului, Colecţia Universitaria, Ed. Dacia, Cluj-Napoca, 378 p.

2. Boar, N. (2005) Regiunea transfrontalieră româno-ucraineană a Maramureşului, Ed. Presa Universitară Clujeană, 294 p.

3. Chiş, V. T., Kosinszki, S. (2011), Geographical Introductary Characterization of the Upper Tisa River Basin (Romania-Ukraine), "The Upper Tisa River Basin", Transylv. Rev. Syst. Ecol. Res., 11, 1-14.

4. Cocuţ, M. (2008) Caracteristicile scurgerii apei din Depresiunea Maramureşului şi zona montană limitrofă, Teză de Doctorat - manuscris, Universitatea BabeşBolyai, Facultatea de Geografie, Cluj-Napoca, 115 p.

5. Lukianets, Olga, Obodovskyi, I. (2015) Spatial, Temporal and Forecast Evaluation of Rivers' Streamflow of the Drainage Basin of the Upper Tisa under the Conditions of Climate Change. Environmental Research, Engineering and Management, 71(1), 36-46.

6. Posea G., Moldovan C., Posea A. (1980), Judeţul Maramureş, Ed. Academiei Române, Bucureşti, 179 p.

7. Smical Irina, Muntean Adriana, Nour E. (2015) Research on the Surface Water Quality in Mining Influenced Area in North-Western part of Romania, Geographica Pannonica, Volume 19, Issue 1, pp. 20-30

8. Ujvári I. (1972) Geografia apelor României, Ed. Ştiinţifică, Bucureşti, 578 p.

9. $* * *(2008)$ Clima României. ANM, Bucureşti.

10. *** (2010) Planul de Management Bazinal. Administraţia Naţională "Apele Române” - Administraţia Bazinală de Apă Somes-Tisa (http://www.rowater.ro/dasomes/Draft\%20Plan\%20Management/Planul\%20de\%2 0Management\%20al\%20spatiului\%20hidrografic\%20Somes-Tisa/).

11. *** (2013), Planul National de Amenajare a Bazinelor Hidrografice din Romania, Administratia Nationala "Apele Romane", Sinteza, Versiune revizuita - Februarie 2013, Bucureşti.

12. *** (2015) Sinteza anuală privind Calitatea Corpurilor de Apă din Spaţiul Hidrografic SomeşTisa. Administraţia Naţională "Apele Române" - Administraţia Bazinală de Apă Somes-Tisa.

13. * * * (2013) Digital Elevation Model over Europe (EU-DEM), http://www.eea.europa.eu/data-and-maps/data/eu-dem

14. *** Romania Geological Map 1: 200,000 Baia Mare and Vişeu sheets. 